\title{
Cause related marketing campaigns and Charity Influence on consumer purchase intentions
}

\author{
Raies Ahmad Mir*, Sheeraz A Thokar**, Mudasir A Mir***
}

\begin{abstract}
Many companies are linking themselves to worthwhile causes to exercise their social responsibility and build more positive images. These days every product seems to be tied with some cause. Companies now sponsor dozens of cause-related campaigns each year. Many are backed by large budgets and a full complement of marketing activities. The findings indicate that consumer purchase intentions are influenced by the charity with cause-related marketing campaigns. Furthermore it was observed that the brand awareness and charity partially mediate the impact of CRM campaigns on consumer purchase intentions. An initial conceptualization was developed from mainstream literature to be validated through empirical research. The conceptualization was then tested with primary quantitative survey data collected from students studying in different colleges of Kashmir Division of state $\mathbf{J} \& \boldsymbol{K}$. Correlation and regression analysis were used to test the key hypothesis derived from literature positioning brand awareness and charity mediating the relationship between CRM and consumer purchase intentions.
\end{abstract}

Key Words: Cause-related Marketing, Charity, Purchase Intentions, Corporate Image, Brand awareness, Kashmir.

\section{Introduction:}

Philanthropy, charity, benevolence and generosity, these are all very good words that should be associated with any type of business. Whether you are a sole proprietor, a large corporation, or a small family business, having your name associated with giving and charity could boost your sales and build brand loyalty. Cause-Related Marketing (CRM) is one of the best ways to connect your business with a good cause.

CRM refers to a commercial activity in which companies and nonprofit organizations form alliances to market an image, product or service for mutual benefit. Some companies also extend their relationship with an organization or a cause beyond marketing, integrating it with other company activities, such as community involvement, employee volunteerism or corporate philanthropy.

Simply providing quality products or services does notsuffice in today's competitive business environment towin the brand can be defined as a strategic alliancebetween the company and a cause for the achievementof mutual benefits (Adkins, 2004). According toVaradarajan and Menon (1988) successfulloyalty of the customers (Dowling and Uncles,1997). That is why the companies are called upon todesign innovative strategies to not only attract the newcustomers but also to retain the existing customersMatson, 1994). In this context, Cause Related Marketing(CRM) represents one of the modern marketing strategies1230 Afr. J. Bus. Manage.(Taylor, 2007) which are being used by most companiesin the western world. Cause related marketing campaignscan increase the sales of the company by increasing trialpurchase, repeat purchase and / or promoting multipleunit purchase. Today, most of the companies are usingCause Related Marketing as a strategic tool (Till andNowak, 2000) to build a positive corporate image in theminds of consumers (Chattananon et al., 2008) whichresults in enhancing the sales of a company's products(Varadarajan and Menon, 1988) and profits as well(Adkins, 2004). Also consumers have better perceptualassociations with those organizations that work withcharities and good causes (Farache and Perks, 2008).During 1983 a cause related marketing program, whichwas launched by the American Express companyresulted in a $\$ 1.7$ million contribution by AmericanExpress to the restoration of the Statue of Liberty. Thecompany promised to contribute one cent for every cardtransaction and $\$ 1$ on the issuance of every new card.Simultaneously, this program also increased the use ofcredit cards by $28 \%$ garneringconsiderable mediacoverage and free publicity (Adkins, 2000; Kotler andKeller, 2006). The 2008 Cone Cause evolution studyconstituted of 1071 adults indicated that about $85 \%$ ofU.S. consumers are more likely to buy from corporationsassociated with a cause or issue. $79 \%$ would be likely toswitch from one brand to another brand, about the samein price and quality, if the other brand is associated with agood cause. 38\% have bought a product associated withthe cause in the last 12 months (Cone communications, 2008).

\section{Cause-related marketing as Powerful marketing edge}

Cause-related marketing can become a cornerstone of your marketing plan. Your cause-related marketing activities should highlight your company's reputation within your target market. Cause-related 
marketing can positively differentiate your company from your competitors and provide an edge that delivers other tangible benefits, including:

$\begin{array}{ll}\text { - } & \text { Increased sales } \\ \text { - } & \text { Increased visibility } \\ \text { - } & \text { Enhanced compromer loyalty } \\ & \text { Positive media coverage }\end{array}$

By choosing a cause you are passionate about, cause-related marketing is emotionally fulfilling. It's a way to merge your profit center with your "passion center" and build a business that mirrors your personal values, beliefs and integrity. If your cause also resonates with your target market, your activities will generate tremendous goodwill and media attention can be its side effect.

In a corporate world characterized by the maxim 'Money is not everything - it's the only thing', many companies are attempting to showcase themselves and their products as harbingers of good to the society of which they are a part of. Defined as the public association of a for-profit company with a nonprofit organization, CRM is intended to promote the company's product or service and to raise money for the nonprofit organizations. Where does cause related marketing fit in There are three conditions that need to be fulfilled for an effective cause-related campaign. - First, there must be a mass feeling for that particular social communication.

- Second, there must be a real or psychological monopolization of the media, which implies the absence of any counter propaganda for the given social cause.

- Third, supplementation that is the effort to follow up the promo with other contacts as and when desired.

This line of thought, when juxtaposed with the fact that e-CRM is simply a manifestation of traditional CRM on a different medium, seems to indicate that e-CRM is a powerful tool for marketers.

\section{Brand awareness and purchase intentions}

In order to answer the primary questions beingempirically set forth in this paper, brand awareness isseen as an important concept for two reasons: first, brandawareness is one of the factors which affect the attitudeof the consumers towards the purchase of products;second, the relationship between CRM and brandawareness had been established in previous research.Nedungad (1990) argued that consumers' inclination topurchase a brand in the market place depends upon theprior knowledge about the brand. Keller (2003) definesbrand awareness as the ability of customers to recall abrand among the clutter of rival brands. In the same vein,Radder and Huang (2008) hold that, especially in highlycompetitive markets, awareness can strongly influence acustomer while buying a product. Consequently, to betterexploit the contributions of brand awareness companiesare using different strategies to create brand awarenessamong the consumers (Schmitt and Geus, 2006). Usingcause related marketing to create brand awareness(Varadarajan and Menon, 1988) leads to enhancedpurchase intentions (Hoyer and Brown, 1990). Accordingly ,Kotler and Keller (2006) regardCause Related Marketing as just one opportunity for thecompanies to enhance the brand awareness. Implyingthe importance of experience on memory building(Kaufmann, 2004), Skory et al (2004) argued that most ofthe companies use CRM to increase brand awarenessamong the consumers through their participation. Socompanies use the cause-related marketing campaignsconsistently over time to change the overall attitude ofconsumers towards the company and its brands (Till andNowak, 2000).

\section{Corporate image and purchase intentions}

Corporate image can be defined as theperception/feelings of customers regarding thecompany's products and activities (Webb and Mohr,1998). It requires a lot of time and enormous resources tobuild a positive corporate image but, on the other hand, itcan help the companies not only in introducing newbrands but also to pick up the sales of existing brands(Markwick and Fill, 1997). In order to build a positivecorporate image in the minds of customers, companiesare using cause related marketing as a strategy(Varadarajan and Menon, 1988; Chattananon et al. 2008) to gain a competitive edge in market place(Anselmsson and Johansson, 2007). As a result of theirstudies, Webb and Mohr (1998) as well as Anselmssonand Johannson (2007) argued that customers' purchaseintentions are influenced by the corporate image of acompany involved in cause related marketing.This paper investigates the nature of the relationshipbetween cause-related marketing, brand awareness,corporate image and consumer purchase intentions. Asmentioned earlier, previous research has shown thatcause-related marketing campaigns can help thecompanies in increasing brand awareness and buildingpositive corporate image in the minds of customers(Varadarajan and Menon, 1988; Adkins, 2004). Thesetwo benefits can be achieved due to increased affectivecustomer affiliations with the company achieved by CRM.

But on the other hand consumer purchase intentions arepre-established, that is consumers are purchasing theexisting products of the company before the company isexecuting the cause related marketing 
campaigns. Thispaper hypothesizes that consumer purchase intentionsmay not be increased through CRM campaigns unless consumersare not able to recognize the products (advertised incause-related marketing campaigns). Implicitly, thepurchase stimulating effect of CRM requires pre-existing(1232 Afr. J. Bus.)Managebrand awareness and positive corporate image.

\section{$>$ Objectives of the Study}

* To analyze the impact of cause-related marketing on brand awareness.

* To analyze the level of awareness among consumers.

* To analyze the influence of charity on purchase intentions of consumers.

\section{$>$ Hypothesis and initial conceptualization}

Following hypothesis can be drawn based on theliterature review:

1) Cause-related marketing campaigns have a positive impact on the brand awareness.

2) There is higher level of awareness among Consumers.

3) The influence of Charity onconsumer purchase intentions towards a product linked with a cause is positive.

\section{Sample and data collection method}

\section{Methodology}

The main objective of the present study was to investigate therelationship between cause-related marketing campaigns;awareness among consumers (involved in Cause-Related Marketing) and ultimately, consumer purchase intentions.To prove these relationships data was collected from 405 students studying in different colleges of Kashmir byusing the convenience sampling technique. These colleges include GDC Boys Baramulla, GDC Sopore, GDC Kupwara, A.S College Srinagar, GDC Bemina, GDC Khanabal Anantnag and GDC Kulgam. These Collegeswere selected due to high level ofdiversity of the respondents hailing from different areas of Kashmir.

A five point likert-scale was used to assessthe respondents' level of agreement or disagreement with eachstatement by circling a number from $1-5$. Before filling in thequestionnaire the respondents were informed about the significanceand purpose of the study. Cause marketing was found relatively anew concept for most of the respondents of the study. To overcomethis impediment and to enhance the validity of the results of currentstudy the respondents were also informed regarding the meaning ofcause related marketing using examples to familiarize them withthis concept.

\section{DATA ANALYSIS AND INTERPRETATION}

Table 1.Demographics of samples.

\begin{tabular}{|l|l|}
\hline Age Mean = 20.71 & Std. Dev. $=\mathbf{2 . 0 1}$ \\
\hline Gender & $\begin{array}{l}\text { Male (\%) 72 } \\
\text { Female (\%) } 28\end{array}$ \\
\hline Education & Bachelors (\%) 100 \\
\hline
\end{tabular}

\section{Reliability analysis}

A summary of the level of reliability achieved with thescales used to measure the dependent and independentvariables in the study is shown in Table 2. Thereliabilities were acceptable as all scales achieve the Cronbach's alpha coefficient greater than 0.7.

\section{Test of hypothesis}

Based up on the literature review and hypothesis design,regression analysis followed by correlation analysis wasfound an appropriate test for the analysis of data. Table 2 contains scale statistics such as means, standarddeviations, and correlations for all variables. The resultsbased on regression analysis are depicted in Table 3.Based upon correlation analysis (Table 2) therelationships hypothesized in H1 through $\mathrm{H} 3$ were allconfirmed to be positive and significant as predicted (alsosee Table 3 for specific path coefficients). The resultsprovide an evidence that cause related marketingcampaigns have a positive impact on brand awareness $\left(0.469^{*}, \mathrm{p}<0.01, \mathrm{H} 1\right.$ supported $)$ and there is high level of brand awareness among the customers $(2.765 \mathrm{p}<0.01, \mathrm{H} 2$ supported).The second step required a test of relationshipbetween the independent variable (CRM campaigns) andthe dependent variable (Charity influence on Consumer purchase intentions).In this step, the relationship was again found positive andsignificant $(\mathrm{p}<0.05)$ which again complies with thestandard.Finally, in the third step the dependent variableneeded to be regressed on both, the 
independentvariable and the mediator. To legitimize mediation, thethird step must find the mediator to be significantlyrelated to the dependent variable and the effect of theindependent variable on the dependent variable to beless than it was in the second step. Furthermore, if therelationship between the independent variable and thedependent variable becomes insignificant in step three,full mediation is supported. In our case, the first criterionwas met as both, brand awareness and awareness among consumerswere still significantly related to charity influencing customer purchaseintentions, and in both cases, the effect of theindependent variable (CRM campaigns) on thedependent variable (customer purchase intentions). These results provide evidence of a partial mediationbetween the variables in question rendering partialacceptance for $\mathrm{H} 3$.

\section{Discussion And Implications}

Being a developing state with a population of morethan 1 crore people, it was very important toinvestigate to what extent the customers' purchaseintentions are influenced by the cause related marketingcampaigns?

The main objective of the present study wasto investigate the relationship between cause-relatedmarketing campaigns, brand awareness, impact of CRM on Brand awareness (involved in Cause-Related Marketing)and ultimately Charity influencing consumer purchase intentions.Conclusively, through the testing of the proposedconceptualization, the study intended to confirm somepreviously established relationships in the setting of Kashmir, and answer the following questions:

(1) Doescharity influence have apositive effect on consumer purchase intentions in Kashmir?

(2) What is the nature of the relationship of thementioned factors, i.e. is it direct, or mediated bybrand awareness?

The results in Table 2 and 3 provide strong evidence that cause-related marketing campaigns positively influencethe consumer purchase intentions in Kashmir which isthe primary contribution of this research paper. Thesefindings confirm the findings of Varadarajan and Menon(1988), Adkins (2004) and Chattananon et al. (2008).Contributing to the body of knowledge, the results alsoindicate that the effect of Cause Related Marketingcampaigns on consumer purchase intentions is partiallymediated by brand awareness and corporate image ofthe company, a fact which was ignored in previousstudies. The results of the structural model and mediationtest provide new insight for the development of differentstrategies to make the Cause Related Marketingcampaigns successful in less developed States suchas Kashmir. The findings suggest that the companiesmust concentrate on increasing the brand awarenessamong the customers so that they can recall the brand set the point of purchase. For this purpose, the effectiveuse of media (electronic and print) for CRM campaignscan play a significant role but there must be a matchbetween the objectives of the company and thepromotional campaign design (Taylor, 2007). Additionally,brand-cause fit can also play a vital role to increase thebrand awareness among the customers (Till and Nowak,2000; Gupta and Pirsch, 2006). Selecting an appropriatecause for a brand can increase the interest of customers.This interest of customers can then lead to the purchaseof the advertised brand. Also brand-cause-culture fitreduces the consumer skepticism and increase theirintention to participate in Cause Related Marketingcampaigns (Web and Mohr, 1998). In this study a realscenario was used to explain the concept of cause-related marketing to the respondents but the questionthat is generated is whether the brand-cause-culture fitresulted in the mediation effect or is this effectindependent of the brand-cause-culture fit.

Table 2.Means, standard deviations, reliability and correlations among the variables.

\begin{tabular}{|l|l|l|l|l|l|l|}
\hline Factor & Mean & Std. Dev. & $\mathbf{1}$ & $\mathbf{2}$ & $\mathbf{3}$ & $\mathbf{4}$ \\
\hline $\begin{array}{l}\text { CRM } \\
\text { campaigns }\end{array}$ & 4.43 & 0.367 & $0.856^{* *}$ & $0.392^{*}$ & $0.334^{*}$ & $0.425^{*}$ \\
\hline $\begin{array}{l}\text { Awareness } \\
\text { among } \\
\text { consumers }\end{array}$ & 4.31 & 0.534 & --- & $0.805^{* *}$ & $0.515^{*}$ & $0.304^{*}$ \\
\hline $\begin{array}{l}\text { Charity } \\
\text { influencing } \\
\begin{array}{l}\text { Purchase } \\
\text { Intentions }\end{array}\end{array}$ & 4.38 & 0.498 & ------ & ------ & ---- & $0.863^{*}$ \\
\hline
\end{tabular}

Notes: $* \mathrm{p}<0.05, \mathrm{n}=405 . * *$ Cronbach's alpha values 
Table 3.Structural model results.

\begin{tabular}{|l|l|l|l|l|}
\hline Hypothesis & $\begin{array}{l}\text { Path } \\
\text { coefficients }\end{array}$ & t- value & $\mathbf{R}^{2}$ & F- value \\
\hline $\begin{array}{l}\text { CRM impact } \\
\text { on brand } \\
\text { awareness }\end{array}$ & $0.469^{*}$ & 5.947 & 0.098 & $19.342^{*}$ \\
\hline $\begin{array}{l}\text { Awareness } \\
\text { among } \\
\text { consumers }\end{array}$ & $0.392^{*}$ & 2.765 & 0.070 & $0.846^{*}$ \\
\hline $\begin{array}{l}\text { CRM - Charity } \\
\text { influencing } \\
\begin{array}{l}\text { Consumer } \\
\text { purchase } \\
\text { intentions }\end{array}\end{array}$ & $0.625^{*}$ & 9.627 & 0.231 & $63.915^{*}$ \\
\hline
\end{tabular}

Notes: $* \mathrm{p}<0.05, \mathrm{n}=405$.

Similarly, the research suggests that firms need toundertake meaningful efforts to improve corporate imageas it mediates the impact of CRM campaigns onconsumer purchase intentions. Although CRM campaignshelp the companies to improve their corporate image(Farache and Perks, 2008), there are also some othermeasures which must be taken into consideration, forexample, the selection of the non-profit organizationreally matters a lot. The company must select anappropriate organization from the target audience point ofview (Boush et al., 1994) and, in this context, that is itsage, education occupation etc. must be considered. Anappropriate selection of the cause can also support thecompany in terms of positive word of mouth from theconsumer. Moreover, the use of an appropriate celebrityfor overall communication strategy (Liu et al., 2007;Silvera and Austad, 2004) in CRM campaigns couldproduce better results for the company reflected inpositive attitudes/feelings of the consumers towards thecompany. In addition, highlighting the contribution tosociety through electronic and print media (Farache andPerks, 2008) can help the companies not only inenhancing brand awareness but also in reducingconsumer skepticism?

\section{Conclusion}

In the present study a complete analysis of Cause-Related Marketing/Corporate Social Responsibility was done and its impact on purchase intentions of people. This study shows that CRM has maximum effect on peoples purchase intentions. It analyses that companies can charge their products higher by linking them with a social cause which has a mass feeling. Our survey shows that CRM (cause-related marketing) is a best tool which has multi-dimensional scope and has capacity to generate multi-benefits. It analyzes that companies with nice image and which deliver quality products have large ambit to link their products with any social cause having mass feeling than new comers in the market.

Lastly but not least the social cause linked with any product or service should be highlighted through advertisements and brand ambassadors so that it can touch the hearts of charity giving people.

\section{References}

[1]. Adkins S (2000). Cause related marketing: who cares wins. Oxford:Elsevier Butterworth- Heinemann.

[2]. Adkins S (2004). Cause related marketing: who cares wins. Oxford:Elsevier Butterworth-Heinemann.

[3]. Anselmsson J, Johansson U (2007). Corporate social responsibility andthe positioning of grocery brands. An exploratory study of retailer andmanufacturer brands at point of purchase. Int. J. Ret. Distrib. Manag.,35(10): 835-856.

[4]. Baron RM, Kenny DA (1986). The moderator-mediator variabledistinction in social psychological research: conceptual, strategic, andstatistical considerations. J. Pers. Soc. Psychol., 51(6): 1173-1182.

[5]. Boush DM, Kim CH, Khale LR, Batra R (1994). Cynicism and conformityas correlates of trust in product information sources. J. Curr. Iss. Res.in Adv., 15(2): 71-79.

[6]. Chattananon A, Lawley M, Supparerkchaisakul N, LeelayouthayothinL(2008). Impacts of a Thai cause-related marketing program oncorporate image. Int. J. Emerg. Mark., 3(4): 348-363.

[7]. Dowling GR, Uncles M (1997). Do Customer Loyalty Programs ReallyWork?. Sloan Manage. Rev., $38(4)$ : $71-82$.

[8]. Kotler P, Keller LK (2006). Marketing Management. 12th Edition,Prentice- Hall, New Jersey.

[9]. Liu MT, Huang YY, Minghua J (2007). Relations among attractivenessof endorsers, match-up, and purchase intention in sport marketing inChina. J. Consumers. Mark., 24(6): 358-365.

[10]. Markwick N, Fill C (1997). Towards a framework for managingcorporate identity. Euro. J. Mark. 31(5-6): 396-409.

[11]. Matson EW (1994). Can Cities Market Themselves Like Coke andPepsi Do? Int. J. Pub. Sec. Manage. 7(2): $35-41$.

[12]. Mohr LA, Eroglu D, Ellen SP (1998). The development and testing of ameasure of skepticism toward environment claims in the marketers'communications. The J. Consumers Aff.. 32(1): 30-55.

[13]. Nedungad P (1990). Recall and Consumer Consideration Sets:Influencing Choice without Altering Brand Evaluations. J. ConsumerRes., 17(3): 263-276.

[14]. Nguyen N, Leblanc G (2001). Corporate image and corporate reputationin customers' retention decisions in services. J. Ret. Consumer Serv.,8: 227-236.

[15]. Rabin, Matthew (1993), “Incorporation Fairness into Game Theory and Economics,” The American Economic Review, 83 (5), 1281 302 
[16]. Radder L, Huang W (2008). High-involvement and low-involvement products. A comparison of brand awareness among students at a South African university. J. Fashion Mark. Manage., 12(2): 232-243.

[17]. Schmitt BH, Geus B (2006). Are brands forever? How brand knowledge and relationships affect current and future purchases. J. Prod. Brand Manage., 15(2): 98-105.

[18]. Silvera DH, Austad B (2004). Factors predicting the effectiveness of celebrity endorsement advertisements. Euro. J. Mark., 38(1112):1509-1526.

[19]. Skory M, Repka S, MCInst M (2004). The Description of Social, Cause-Related Marketing and Corporate Social Responsibility. J. the Can. Inst. Mark., 7(2): 1-27.

[20]. Taylor LR (2007). Cause-related marketing: a new perspective on achieving campaign objectives amongst fast moving consumer goods. Strat. Change, 16: 79-86.

[21]. Till BD, Nowak LI (2000). Toward effective use of cause-related marketing alliances. J. Prod. Brand Manage. 9(7): 472-484.

[22]. Van Den Brink D, Odekerken-Schro“Der G, Pauwels P (2006). The effect of strategic and tactical cause-related marketing on consumers' brand loyalty. J. Consum. Mark., 23(1): 15-25.

[23]. Varadarajan PR, Menon A (1988). Cause related marketing: a coalignment of marketing strategy and corporate philanthropy. J. Mark. 52(3): 58-74.

[24]. Webb DJ, Moh LA (1998). A typology of consumer responses to cause related marketing: From skeptics to socially concerned. J. Pub. Policy Mark, 17: 226-39. 